\title{
The potential of cassava leaves extract in gingival fibroblasts of periodontitis of rats with ovarian dysfunction
}

\author{
Amandia Dewi Permana Shita ${ }^{1 *}$, Zahara Meilawaty ${ }^{1}$, Dhesyarmani Putri Rothschildi ${ }^{1}$, \\ Agustin Wulan Suci Dharmayanti ${ }^{1}$, Zahreni Hamzah ${ }^{1}$
}

${ }^{1}$ Department of Biomedic, Faculty of Dentistry Jember University, Indonesia

\begin{abstract}
Introduction: The prevalence of periodontitis has reached $42.8 \%$ in Indonesia. One contributing factor is Porphyromonas gingivalis. The ovarian dysfunction caused by ovariectomy procedures may also cause periodontitis. Post ovariectomy conditions resemble menopause, lowering the production of estrogen and progesterone hormones, leaving patients vulnerable to periodontitis. To prevent the side effects of the treatment, herbal ingredients are commonly used. The extract of cassava leaves is known to have pharmacological effects as an antioxidant and, thus, can be applied as a medicine for periodontitis. Methods: A total of 21 rats were divided into three groups, (1) control: healthy rats; (2) Group P.1: P. gingivalis-induced rats; (3) Group P.2: ovariectomized rats. Groups P.1 and P.2 were further divided into three subgroups that were administered cassava leaves extract at a dosage of $179.2 \mathrm{mg} / \mathrm{kg} \mathrm{BW}$, aquades and vitamin C. Rats were euthanized at day eight after the initial treatment to collect left mandibular first molar. The mandibular sections were immunohistochemically stained to quantify SOD expression using light microscope while the Image J software was used. Fibroblast cells expressing SOD are characterized by brown coloration in the cytoplasm and darker nucleus. Results: In periodontitis conditions, either due to P.gingivalis induction or ovarian dysfunction, fibroblast cells in rats given cassava leaves extract expressed higher SOD than rats given aquades, but still lower than rats given vitamin $C$. The result of the one way ANOVA test showed $p$ value of 0,00 , which means that there is a significant difference in all groups. Conclusion: Cassava leaves extract demonstrated the potential to increase the antioxidant expression in $P$. gingivalis-induced and ovarian dysfunction rats.
\end{abstract}

Keywords: Cassava leaves extract; SOD; Porphyromonas gingivalis; ovarian dysfunction

p-ISSN: 1979-0201; e-ISSN: 2549-6212; Available from: http://jurnal.unpad.ac.id/pjd/article/view/29611

DOI: $10.24198 / p j d . v o l 33 n o 2.29611$

Submission: Sep 27, 2020; Accepted: Nov 30, 2021; Published online: Nov 30, 2021

INTRODUCTION

Periodontitis is a chronic inflammatory microbial disease that directly damage the tooth-supporting structure. ${ }^{1}$ Currently, periodontitis sufferers in
Indonesia reach $74,1 \%$. According to the basic health research (RISKESDAS) data in 2018, East Java Province has the second highest number of people with oral and dental problems after West Java Province. ${ }^{2}$ The severity of periodontitis 
ranges from mild and reversible inflammation of the gingiva (gingivitis) to chronic destruction of connective tissue, gingival bleeding, the formation of periodontal pocket, attachment loss, radiographically assessed alveolar bone loss, and ultimately result in loss of teeth. ${ }^{3-4}$ Periodontal disease represents a group of oral inflammatory infections initiated by oral pathogens which exixt as a complex biofilms on the tooth surface and cause destruction to tooth supporting tissue. ${ }^{4}$

Among major periodontal pathogens, Porphyromonas gingivalis ( $P$. gingivalis) appears to be one of the prime etiological agents in the pathogenesis and progression of the inflammatory events of periodontal disease. ${ }^{5}$ One of the bacteria present in the oral plaque biofilm is Porphyromonas gingivalis (P. gingivalis). ${ }^{6} P$. gingivalis is able to attack epithelial cells of the gingival mucosa, and endothelial cells. ${ }^{7}$

The toxin of $P$. gingivalis reduce the level and activity of endogenous Superoxide Dismutase (SOD), thereby causing oxidant-antioxidant imbalance and triggering oxidative stress. ${ }^{8}$ SOD is an enzymatic antioxidant that exist in three forms in mammalian tissues and differs on their cofactor, subcellular location and tissue distribution. It is synthesized only in fibroblasts and endothelial cells and expressed on the cell surface. ${ }^{9}$

Several studies described a bidirectional relationship between female reproductive organ function and periodontitis, although that mechanism is still unclear. ${ }^{10,11}$ The systemic and oral health correlates to sex steroid hormone alteration, where the hormones are involved in the body's metabolic processes, including maintaining the integrity of oral health and diversity of the oral microorganism. ${ }^{12,13}$ Hormonal imbalance increases oral bacteria's virulence, especially Porphyromonas gingivalis, and triggers oral tissue diseases, such as periodontitis. Several studies suggested that periodontitis is correlated to hormonal alteration, especially in female reproductive organ function in menopause and pregnancy. ${ }^{13,14}$

Periodontitis treatment that is done at this time can cause side effects so that the idea of using herbs as a treatment emerges. Many staple plants can be used as herbal plants. One of them is cassava. Many benefits of the parts contained in cassava, one of which is the leaves. Cassava leaves have many benefits in the health world because they have a high content of vitamin C (around $27.5 \%$ ), organic compounds flavonoids, quercetin, triterpenoids, tannins and saponins. Flavonoids, tannins and vitamin $C$ contained in cassava leaves extracts act as exogenous antioxidants. ${ }^{15}$ Cassava leaves also contain carotene and iron as enzymatic antioxidant cofactors. ${ }^{16-17}$ In addition, chlorophyll in cassava leaves also act as an antioxidant which is a major barrier to oxidation reactions. The content of vitamin $C$ in cassava leaves almost reaches four times the content of vitamin $C$ in cassava tubers, while the carotene content is only found in cassava leaves. ${ }^{18}$

Superoxide dismutases (SODs) are localized in the cytosol and the mitochondrial intermembrane, the mitochondrial matrix and inner membrane, and extracellular compartment. The use of cassava leaves to increase antioxidant activity can be seen from the expression of SOD gingival fibroblasts. SOD catalyzes the conversion of the superoxide anion free radical to hydrogen peroxide and molecular oxygen. ${ }^{19}$ SOD activity in the body can be related to menopausal conditions, the marked reduction in estrogen has been shown to increase levels of oxidative stress in the body, depending on the concentration and chemical structure of this hormone. ${ }^{20}$

Lack of the hormone estrogen can be overcome by menopausal hormone therapy (HMT). including estrogen-alone therapy (ET) and estrogen plus progestin therapy (EPT). However, MHT was associated with increased risks of venous thromboembolism, endometrial cancer, endometrial hypoplasia, bone loss and fracture, cerebrovascular disease, asthma, etc. ${ }^{21}$ Therefore, treatment using herbal plants is the choice.

Based on preliminary researches, the results showed that the dose of cassava leaves extract which was effective in inhibiting the growth of $P$. gingivalis bacteria was $179.2 \mathrm{mg} /$ $\mathrm{kg}$ BW. ${ }^{22}$ Therefore, the authors would like to examine the potential of cassava leaves extract with these doses on gingival SOD expression of periodontitis rat models and those with ovarian dysfunction. The purpose of this study was to determine the potential of cassava leaves extract for the expression of SOD in gingival fibroblasts of periodontitis and rat models that have ovarian dysfunction. 


\section{METHODS}

An experimental laboratory study with the posttest only control group design was conducted in October 2019 - January 2020. The rats were kept in the Animal Room of the Faculty of Dentistry Jember University, given an initial examination for systemic health conditions and stored in boxes with sawdust. All animals were kept at room temperature with controlled humidity. The animals used had been approved by the Ethics and Advocacy Unit, Faculty of Dentistry Gadjah Mada University with the approval number of 00277/ KKEP/FKG-UGM/EC/2019.

\section{Groups and treatment}

The animals were grouped into 2 groups of treatment and 1 group of control. The first group of treatment was the P.gingivalis induced group and the second one was the ovariectomy group. In the P.gingivalis induced group and the ovariectomy group each was divided into 3 sub-groups, namely the sub-group given extracts of cassava leaves, distilled water and vitamin C.

\section{Making of Cassava Leaves Extract}

Cassava leaves are obtained from a sub-district in the Jember district. Furthermore, cassava leaves are identified in Lembaga Ilmu Pengetahuan Indonesia (LIPI); Balai Konservasi Tumbuhan (BKT) Kebun Raya Purwodadi, Malang, East Java. Cassava leaves extract is made at the Integrated Analysis Laboratory, Faculty of Agricultural Technology, University of Jember. This process begins with the selection of cassava leaves. Leaves picked are the 5 th leaves from the shoots, washed clean, then cut into small pieces and dried by aerating for 2 days at room temperature that is not exposed to direct sunlight. Then the cassava leaves are dried in the oven at $40^{\circ} \mathrm{C}$ for 24 hours straight. The weight of dried cassava leaves became 238.54 grams and then smoothed and sieved ( 80 maze) to obtain 207.25 grams of fine powder. The powder was macerated with $96 \%$ ethanol with a simplicia: solvent ratio of 1: 6 for 2 days and stirred every 24 hours. The solution was concentrated with a rotary evaporator with a temperature of $50^{\circ} \mathrm{C}$ and a rotation of $90 \mathrm{rpm}$ until its extract concentration became $100 \%$ semisolid. ${ }^{5}$ The dose given is 179.2 $\mathrm{mg} / \mathrm{kgBW}$ rat. The preparation was obtained by dissolving $8.96 \mathrm{mg}$ of cassava leaves extract in $1 \mathrm{ml}$ of distilled water and $10 \mathrm{ml}$ of propylene glycol. After the preparations are made, they are directly given to animals orally.

\section{Preparation of Vitamin C}

The dose of vitamin C given to rats was $500 \mathrm{mg} /$ $\mathrm{kgBB} /$ day (human dose) which was converted to rat to $2.25 \mathrm{mg} / \mathrm{kgBB} /$ day. This dose was assessed as the optimal dose in rats that did not cause death. Vitamin $\mathrm{C}$ as much as $2.25 \mathrm{mg}$ was dissolved in $1 \mathrm{ml}$ of distilled water and $5 \mathrm{mg} 0.5 \% \mathrm{Na}$-CMC.

\section{Preparation of Experimental Animals}

Preparation of experimental animals was carried out in the Pharmacology Laboratory of the Biomedical Faculty of Dentistry, University of Jember. The total number of samples was 21 female Sprague-Dawley rats weighing \pm 200 grams, aged 2-3 months, in a healthy condition marked by the response of their active movements and not deformed. The experimental animals were adapted for 1 week with a new environment. The sample was divided into 3 groups: the control group (healthy/normal), group P.1 (induction of P.gingivalis bacteria), group P.2 (ovariectomy). In groups P. 1 and P. 2 were divided into 3 subgroups each given cassava leaves extract, aquadest and vitamin C. Decapitation was carried out on the 8th day in each group.

\section{The Model of Rat Ovarian Dysfunction}

Rats were anesthetized intramuscularly with xylazine and ketamine. The animal dissection was conducted in the proper procedure standard. The incision of 4-8 cm was done in the orientation area, after the open abdominal cavity was cut in the ovary (granule-shaped-like grapes). Betadine was applied to an open rat wound, then sutured. After the stitches were finished, $3 \%$ iodine tincture was given.

\section{The Model of Rat Periodontitis}

The periodontitis rat model was a female Sprague Dawley rat induced by $P$. gingivalis bacteria in the lingual and buccal gingiva of the mandibular left first molar. The dose given in each section is 0.5 $\mu \mathrm{g} / 0.05 \mathrm{ml}$. It is done every 3 days for 14 days using a tuberculin syringe with a size of 30 -gauge needle. 


\section{Immunohistochemistry assay}

3 rats from each group were euthanized on day 8 , after which tissue decalcification was performed. The process of immunohistochemical staining was carried out at the Histology Laboratory of the Biomedical Department of the Faculty of Dentistry, Jember University.

Immunohistochemical staining was initiated by deparaffinization (xylol I, II, III) and rehydration (ethanol $100 \%$ and $95 \%$ ) for 3 minutes, respectively. The tissue preparations were washed using distilled water for 10 minutes and given PBS (pH 7.4) for 5 minutes, then dried. The preparations were dripped with $\mathrm{H} 2 \mathrm{O} 23 \%$, and let it sit for 10 minutes, then washed again using PBS, then the preparations were dripped with Ultra $V$ Block, let it sit for 5 minutes, then re-washed with PBS for 5 minutes, then dried.

The primary antibody was dripped with $\mathrm{Cu}$ monoclonal primary antibody, Zn-SOD biorbyte (catalog number: orb67357) and incubated for 24 hours at $40 \mathrm{C}$. The preparation is removed and allowed to sit at room temperature for 15-30 minutes. The preparations were washed with PBS and then dried. The preparations were dripped with Biotinylated Goat Anti-Polyvalent, let it sit for 10 minutes and washed using PBS for $4 \times 5$ minutes. The preparations were dripped with Streptavidin Peroxidase, let it sit for 10 minutes then washed again with PBS. DAB plus Chromogen is applied by dropping it on the preparation, covering it with aluminum foil and then leaving it for 5-15 minutes. The preparations were washed using PBS for $4 \times 5$ minutes, followed by distilled water and then dried. The preparations were given hematoxylin dye, let it sit for 2 minutes and then washed using distilled water.

The preparation is dehydrated with alcohol and cleared it with xylol. The last stage is mounting using entelan. ${ }^{23-24}$ The results of immunohistochemical staining against SOD were observed. Histological observations were carried out using a microscope with the help of OptiLab 2.2 and the application of Image J and Immunoratio with a magnification of $400 x$.

\section{Statistical analysis}

The data obtained were edited and tabulated, then a data normality test was performed to see the data distribution. The normality test used the Shapiro Wilk test, then the data homogeneity test was carried out using the Levene test. The result was that the data was normally distributed and homogeneous, then an ANOVA one way parametric statistical test was carried out with a confidence level of $95 \%(p<0.05)$ using SPSS 20 for Windows ${ }^{\circledR}$ software and continued with the Least Significant Difference (LSD) test.

\section{RESULTS}

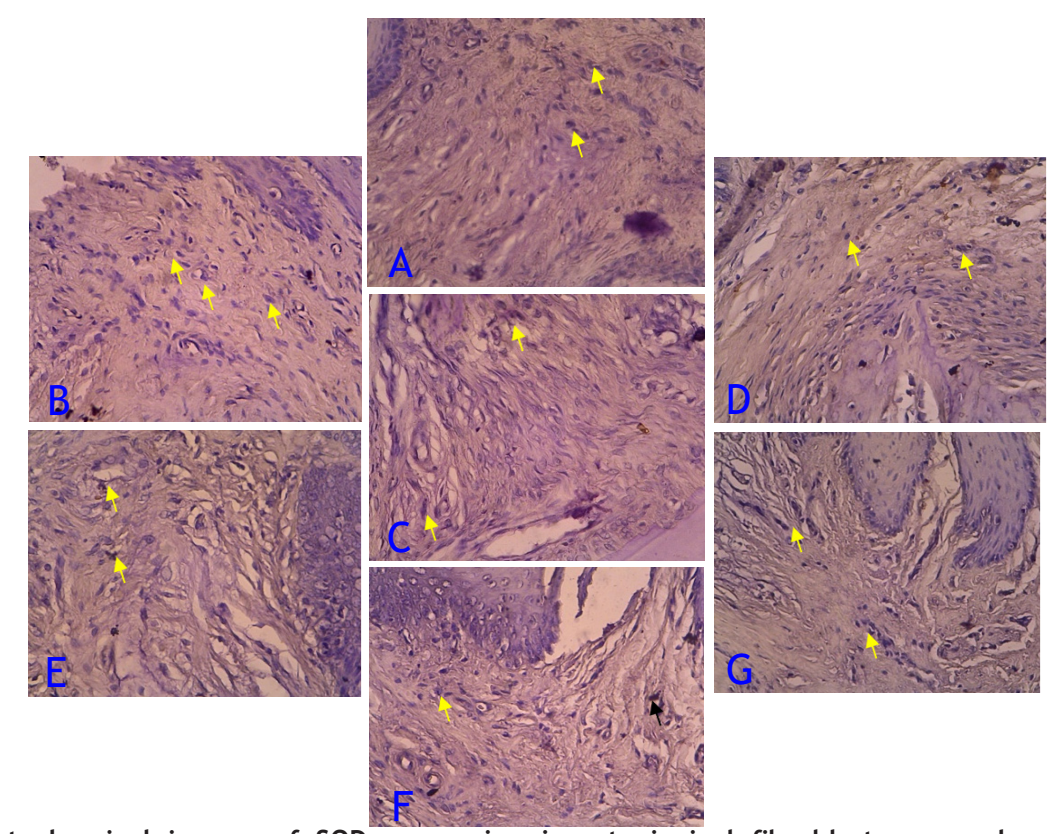

Figure 1. Immunohistochemical images of SOD expression in rat gingival fibroblasts were shown with yellow arrows (magnification 400x). a. Control; b. P.1.1; c.P.1.2; d.P.1.3; e.P.2.1; f. P.2.2; g. P.2.3. 
Based on the research that has been done, a clinical figure of female Sprague-Dawley rats that have been treated and euthanized on day 8 is obtained, namely reddish gingiva and bleeding. On the radiographic examination, there was a radiolucent image around the teeth that indicated the presence of bacterial infection and destruction of the periodontal tissue in the bacterial-induced group as well as in the group with ovarian dysfunction.

Histologically, observations were made on the gingival area to determine the description of SOD expression in gingival fibroblasts. An image of rat gingival fibroblasts expressing SOD is shown in Figure 1 below. Figure 1. SOD Expression in the fibroblast of rats models in control and treatment groups. Observation was taken under light microscope by $400 x$ magnification and analysed using Image-J software program. SOD expression in rat gingival fibroblasts were shown with yellow arrows.a) Healthy rat; Periodontitis induced P.gingivalis treatment with cassava leaves extract (b), aquadest (c), vitamin C (d); Periodontitis cause of ovarian dysfunction treatment with cassava leaves extract (e), aquadest (f), vitamin C (g). Histologically, observations were made on the gingival area with a $400 x$ magnification to determine the description of SOD expression in rat gingival fibroblasts. The results showed that there were differences in SOD expression in rat gingival fibroblasts. The group that was given vitamin $\mathrm{C}$ both in the group induced by $P$. gingivalis bacteria and those that were carried out by ovariectomy had the most dominant results of SOD expression, followed by the group that was given extracts of cassava leaves and aquadest. The mean expression of SOD in rat gingival fibroblasts is shown in Table 1 below.

Table 1. The mean expression of SOD in rat gingival fibroblasts

\begin{tabular}{|c|c|c|c|c|c|}
\hline & Groups & $\mathbf{N}$ & Mean \pm SD (\%) & Shapiro Wilk test & ANOVA \\
\hline & $\mathrm{K}$ & 3 & $14.3 \% \pm 4,05 \%$ & 0,26 & \\
\hline & P.1.1 & 3 & $19 \% \pm 0.56 \%$ & 0,510 & \\
\hline & P.1.2 & 3 & $13.3 \% \pm 0.91 \%$ & 0,637 & \\
\hline & P.1.3 & 3 & $33.2 \% \pm 4.82 \%$ & 0,480 & 0,00 \\
\hline & P.2.1 & 3 & $22.3 \% \pm 1.7 \%$ & 0,935 & \\
\hline & P.2.2 & 3 & $13.7 \% \pm 2.85 \%$ & 0,981 & \\
\hline & P.2.3 & 3 & $35.5 \% \pm 2.68 \%$ & 0,394 & \\
\hline $\mathbf{N}$ & \multicolumn{5}{|l|}{ = sample } \\
\hline K & \multicolumn{5}{|c|}{$=$ control group } \\
\hline \multicolumn{6}{|c|}{ P.1.1 = induced by $P$. gingivalis + cassava leaves extract } \\
\hline \multicolumn{6}{|c|}{ P.1.2 = induced by $P$. gingivalis + aquadest } \\
\hline \multicolumn{6}{|c|}{ P.1.3 = induced by $P$. gingivalis + vitamin C } \\
\hline \multicolumn{6}{|c|}{ P.2.1 = ovariectomy + cassava leaves extract } \\
\hline \multicolumn{6}{|c|}{ P.2.2 = ovariectomy + aquadest } \\
\hline \multicolumn{6}{|c|}{ P.2.3 = ovariectomy + vitamin C } \\
\hline
\end{tabular}

In the control group, the histological picture was seen with a $400 x$ magnification of the SOD expression of gingival fibroblasts with a value of $14.3 \%$. The treatment group induced by P.gingivalis + cassava leaves extract was 19\% and the ovariectomized group + cassava leaves extract was $22.3 \%$. It can be seen that the histological features of the SOD expression of gingival fibroblasts are both higher than the control group. The score for the treatment group induced by P.gingivalis + aquades was $13.3 \%$ and the value for the ovariectomy + aquades group was $13.7 \%$. It can be seen that the histological features of the SOD expression of gingival fibroblasts are both lower than the control group. The treatment group induced by P.gingivalis + vitamin $\mathrm{c}$ had a value of $33.2 \%$ and the group that was ovariectomized + vitamin c had a value of $35.5 \%$. It can be seen that the SOD expression of gingival fibroblast cells is both higher than the control and group that were given cassava leaves extract and those given aquades.

The results of the research data were tested for its normality with the Shapiro-Wilk test and homogeneity with the Levene test. The test results show that all data are normally distributed with a $\mathrm{p}$ value $>0.05$ and homogeneous with a $\mathrm{p}$ value $>0.05$. Because the data were normally distributed and homogeneous, it was continued with the one-way ANOVA parametric test. The 
one-way ANOVA test result has a significance value of 0.00 , which means that there are significant differences in all groups. Then proceed with the
LSD statistical test which showed differences in SOD expression in several groups, marked with a significance value of $\mathrm{p}<0.05$.

Table 2. LSD test results of SOD expression of rat gingival fibroblasts

\begin{tabular}{cccccccc}
\hline Groups & $\mathrm{K}$ & $\mathrm{P} 11$ & $\mathrm{P} 12$ & $\mathrm{P} 13$ & $\mathrm{P} 21$ & $\mathrm{P} 22$ & $\mathrm{P} 23$ \\
\hline K & - & 0.068 & 0.670 & $0.00^{*}$ & $0.004^{*}$ & 0.804 & $0.00^{*}$ \\
P11 & & - & $0030^{*}$ & $0.00^{*}$ & 0.182 & - & - \\
P12 & & - & $0.00^{*}$ & - & 0.858 & - \\
P13 & & & - & - & - & 0.342 \\
P21 & & & & $-003^{*}$ & $0.00^{*}$ \\
P22 & & & & & - & $0.00^{*}$ \\
P23 & & & & & & - \\
\hline
\end{tabular}

* = significant difference

The LSD test showed differences in SOD expression in several groups, marked with a significance value of $p<0.05$. However, several other groups showed no significant difference, namely in group $K$ against group P.1.1, P.1.2, and P.2.2, group P.1.1 against P.2.1, group P.1.2 against group P.2.2, group $P$.1.3 against group P.2.3.

\section{DISCUSSION}

The results of calculating the SOD expression of gingival fibroblast cells in the control group, namely healthy rats, showed that the value of fibroblast cells would still express SOD because SOD was an endogenous antioxidant in the body, so physiologically it would remain expressed in cells to compensate for the presence of reactive oxygen species (ROS) that remained constant, produced even under normal conditions. ${ }^{25}$

Observations were made on the group induced by $P$. gingivalis bacteria and the ovariectomy group, both were given aquades, it was seen that both groups experienced periodontitis. The group of rat induced by $P$. gingivalis bacteria can experience periodontitis because these bacteria produce collagenase, proteases, hemolysins, endotoxins, fatty acids, ammonia, hydrogen sulfide and indole which can initiating immune and inflammatory response, thereby facilitating periodontitis. ${ }^{7,26,27}$

The group of rat with ovarian dysfunction also experienced periodontitis. This is because estrogen deficient might exhibit accordingly a decreased epithelial keratinization of marginal gingiva, and desquamation of gingival tissue where gingiva decreases in size and has a smooth surface with mottled appearance, alveolar bone resorption, reduce bone formation which can lead to periodontitis. ${ }^{28}$ Meanwhile, aquadest did not have any active ingredients that could play a role in increasing the SOD expression of gingival fibroblasts, so the expression of both was lower than the control group.

The expression of SOD gingival fibroblasts in the group of periodontitis rats induced by $P$. gingivalis bacteria which treated with cassava leaves extract and the group of ovariectomized rat which given the same extract showed a higher value than the control group. This result inline with the research of Simao et $\mathrm{al}^{29}$ which stated that the ability of cassava leaves in reducing free radicals due to the presence of flavonoids, tannins and vitamin $C$ which act as antioxidants. As polyphenolic compounds, flavonoids, have the ability to act as antioxidant by a free radical scavenging mechanism with the formation of less reactive flavonoid phenoxyl radicals. ${ }^{30}$

In response to increased oxidative stress, plants such a cassava leaves augment the production and accumulation of several low molecular weight antioxidants (e.g., vitamin C) and high molecular antioxidant secondary metabolites such as tanins, which confer antioxidants by functioning as free radical scavengers, reducing agents, and metal chelators.

Cassava leaves have efficient complex enzymatic and non-enzymatic antioxidant defense system to avoid the toxic effects of free radicals. Enzymatic systems include SOD, catalase (CAT), glutathione peroxidase (GPx), and glutathione 
reductase (GR), while non-enzymatic systems consist of low molecular weight antioxidants (ascorbic acid, glutathione, proline, carotenoids, phenolic acids, etc) and high molecular weight secondary metabolites such as tannins.

Vitamin $C$ is generated during aerobic metabolism, after which it reacts rapidly with $\mathrm{O}_{2}$, singlet oxygen and $\mathrm{H}_{2} \mathrm{O}_{2}$ through ascorbate peroxidase to neutralize the toxic effects. In cassava leaves, phenolics can acts as antioxidants by donating electrons to guaiacol-type peroxidases for the detoxification of $\mathrm{H}_{2} \mathrm{O}_{2}$ produced under stress conditions. ${ }^{31}$

Rat gingival fibroblast SOD expression was also carried out in the group of periodontitis rats induced by $P$. gingivalis bacteria which given vitamin $C$ and those that were ovariectomized which given the same treatment, the score was also higher than the control group.

This is because the ability of vitamin $C$ to increase antioxidant activity (SOD) is the same both in the conditions of periodontal disease induced by $P$. gingivalis bacteria and those caused by hormonal changes. The group given vitamin $C$ was higher than those given cassava leaves extract. This is because cassava leaves are one of the herbal plants, while vitamin $C$ is a synthetic material which can act as pro-oxidant and it can generate hydrogen peroxide, protects the immune system and the absorption time of the drug is faster when compared to herbal plants. ${ }^{32-33}$ Vitamin C affects several components of the human immune system.

Vitamin C appears to play a role in a number of neutrophil functions including increased chemotaxis, increased particulate ingestion, enhanced lysozyme-mediated nonoxidative killing, protection against the toxic effects of superoxide anion radical. Vitamin C inhibits the excessive activation of the immune system to prevent tissue damage. It also supports antibacterial activity, stimulates natural killer (NK) cells and differentiation of Th0 subset into Th1 subset. In addition, vitamin $\mathrm{C}$ also modulates synthesis of proinflammatory cytokines, or expression of adhesive molecules. ${ }^{34}$ However, the use of synthetic drugs for a long time can cause side effects ranging from inflammation to liver damage and increases the risk of carcinogenic diseases. ${ }^{35}$

\section{CONCLUSION}

The cassava leaves extract can increase SOD activity in the gingival fibroblasts of periodontitis rats model cause of P.gingivalis and ovarian dysfunction. In addition, the expression of SOD in gingival fibroblasts treated with cassava leaves extract in both the group experiencing periodontitis and ovarian dysfunction had the same value (there was no difference).

\section{REFERENCES}

1. Tuhuteru DR, Lampus BS, Wowor VNS. Status Kebersihan Gigi dan Mulut Pasien Poliklinik Gigi Puskesmas Paniki Bawah Manado. Jurnal e-Gigi (eG). 2014; 2(2): 1-5. DOI: $10.35790 /$ eg.2.2.2014.5437

2. Tayebrezvani HP, Moradi, Soltani F. The Effect of Nitrogen Fixation and Phosphorus Solvent Bacteria on Growth Physiology and Vitamin C Content of Capsicun annum L. Iran J Plant Physiology. 2013; 3(2): 673-82.

3. Nurhayati $S$, Kisnanto $T$, Syaifudin $M$. Superoxide Dismutase (SOD): Apa dan Bagaimana Peranannya Dalam Radioterapi. J IPTEK Ilmiah Populer. 2011; 13(2): 67-74

4. Syarif A, Ascobat P, Estuningtyas A, Setiabudy R, Setiawaty A. Farmakologi dan Terapi. $6^{\text {th }}$ ed. Jakarta: Badan Penerbit FK-UI; 2016

5. Widyaningsih I, Inawati, Tjandra L. 2017. Kandungan Xanton dalam Ekstrak Kulit Manggis dengan Pelarut Etanol Absolut. J Ilmiah Pend Eksakta. 3(2): 225-34.

6. Raden A. Efek Ekstrak Pegagan (Centella Asiatica) pada Rattus Norvegicus Wistar yang Dilakukan Ovariektomi Terhadap Proliferasi Epitel pada Dinding Vagina. J Ilmiah Ked Hewan. 2011; 4(1): 71-76. DOI: 10.2991/ assehr.k.200218.047

7. Wresdiyati T, Sinulingga TS, Zulfanedi Y. Effect of Mamordica charantia L. powder on antioxidant superoxide dismutase in liver and kidney of diabetic rats. Hayati Journal of Biosciences. 2010; 17(2): 53-7. DOI: $10.4308 /$ hjb.17.2.53

8. Pavani B, Kumar S, Ramarao J, Rao BR, Mohanty S. Role of Biochemical Markers for Evaluation of Oxidative Stress in Senile Cataract. IJBPS. 2012; 2(2): 178-84 
9. Samaranayake, L. Essential Microbiology for Dentistry. $5^{\text {th }}$ ed. China : Elsevier; 2012. pp. 400

10. Genco RJ, Williams RC. Periodontal Disease and Overall Health: A Clinician's Guide. Pennsylvania: Professional audience Communications, Inc; 2010

11. Hasanah A. Efek Jus Bawang Bombay (Allium Cepa Linn.) terhadap Mortilitas Spermatozoa Mencit yang Diinduksi Streptozotocin (STZ). E Journal. 2015; 11(2): 92-10. DOI: 10.22219/ sm.v11i2.4203

12. Puspitarini BA. Uji Aktivitas Antioksidan Ekstrak Daun Singkong (Manihot Folium) Menggunakan Metode Diphenylpicyrl Hydrazyl (DPPH). Skripsi. Yogyakarta: Fakultas Farmasi Univesitas Sanata Dharma; 2010. DOI: $10.22219 / \mathrm{sm} . \mathrm{v} 11 \mathrm{i} 2.4203$

13. Chalopin M, Tesse A, Martinez MC, Rognan D, Arnal JF, Andriantsitohaina R. Estrogen Receptor Alpha as a Key Target of Red Wine Polyphenols Action on The Endothelium. PLoS One. 2010; 5(1): e8554. DOI: 10.1371/journal. pone. 0008554
14. Lung JKS, Destiani DP. Uji Aktivitas Antioksidan Vitamin A, C, E dengan Metode DPPH. Farmaka. 2017; 15(1): 53-62. DOI: 10.24198/ jf.v15i1.12805

15. Taghvaei M, Jafari SM. Application and Stability of Natural Antioxidants in Edible Oils in Order to Substitute Synthetic Additives. J Food Sci Technol. 2015; 52(3): 1272-1282. DOI: $10.1007 / \mathrm{s} 13197-013-1080-1$

16. Ningsih N, Yasni S, Yuliani S. Sintesis Nanopartikel Ekstrak Kulit Manggis Merah dan Kajian Sifat Fungsional Produk Enkapsulasinya. J. Teknol dan Industri Pangan. 2017; 28(1): 27-35. DOI: $10.6066 /$ jtip. 2017.28.1.27

17. Isnidar WS, Setyowati EP. Isolasi dan identifikasi senyawa antioksidan daun kesemek (diospyros kaki thunb.) dengan metode DPPH (2,2-difenil1-pikrilhdrazil). Majalah Obat Tradisional. 2011; 16(3): 157-164

18. Jin L, Zhang Y, Yan L, Guo Y, Niu L. Phenolic Compounds and Antioxidant Activity of Bulb Extracts of Six Lilium Species Native to China. Molecules. 2012; 17(8): 9361-9378. DOI: $\underline{10.3390 / \text { molecules } 17089361}$ 